\title{
Low hydrogen concentrations in ancient oceanic mantle lithosphere: a case study from the Gong Tso ophiolitic peridotites, southern Tibet
}

\author{
JIA-NING ZHAO, YONG-FENG WANG AND QIANG LIU
}

China University of Geosciences (Wuhan)

Presenting Author: zhaojianing@cug.edu.cn

Hydrogen distribution and its controlling parameters in oceanic mantle environments remain poorly constrained, mainly due to the difficulty in sample collection and the effects of strong alteration. However, ophiolitic peridotites, which represent relict fragments of old oceanic mantle, could provide an alternative to touch these problems. Here we present a detailed analysis of mineral chemistry and hydrogen concentrations for 14 lherzolites and 2 harzburgites from the Gong Tso ophiolite in the Yarlung Zangbo suture zone, southern Tibet. The Gong Tso peridotites have olivine $\mathrm{Mg} \#$ (0.89-0.91), orthopyroxene $\mathrm{Al}_{2} \mathrm{O}_{3}$ (2.6-5.3 wt.\%), spinel Cr\# ( 0.2-0.4), and spinel $\mathrm{Mg} \#(\sim 0.5-0.7)$ values comparable to those of typical abyssal peridotites. Both spinel $\mathrm{Cr} \#$ and clinopyroxene trace elements point to that the Gong Tso peridotites have experienced $\sim 5-15 \%$ partial melting. The rare earth element (REE) patterns of clinopyroxene, characterized by strong depletion in LREE $\left(\mathrm{La}_{\mathrm{N}}=0.002-0.076\right.$ and $\mathrm{Ce}_{\mathrm{N}}=0.005$ 0.114 ), are similar to those from abyssal peridotites and indicate partial melting instead of metasomatic processes. The absence of significant anomalies in LILE and HFSE in clinopyroxene also suggests that the Gong Tso peridotites scarcely experience metasomatism after melt extraction. Fourier transform infrared (FTIR) measurements show that olivine is essentially dry and orthopyroxene contains a hydrogen concentration of 24-92 wt ppm. Hydrogen concentration in clinopyroxene cannot be measured reliably due to abundant exsolution lamellae and intense alteration. While olivine loses completely its hydrogen concentrations, orthopyroxene most likely preserves its original hydrogen concentration of mantle source, as suggested by the observed homogeneous distribution of hydrogen between cores and rims. The hydrogen concentrations of orthopyroxene reported here are relatively lower when compared with those ( 10-400 wt ppm) of orthopyroxene within abyssal peridotites. This is consistent with partial melting as the dominant process controlling the mineral chemistry compositions of our samples. In contrast, the relatively higher hydrogen concentrations in modern oceanic mantle are generally associated with different types of metasomatism. However, our data show that no clear correlation exists between hydrogen concentrations in orthopyroxene and partial melting indices. This discrepancy remains an open question, but subsolidus re-equilibration could be a contributor. 